\title{
LOUIS AGASSIZ AS A TEACHER
}

\author{
ILLUSTRATIVE EXTRACTS ON \\ HIS METHOD OF INSTRUCTION
}

WITH AN INTRODUCTORY NOTE

\author{
BY \\ LANE COOPER \\ PROTLBSOR OF THE ENGUTBE LANGUAGE AND IITMRATURE \\ IN CORNELL ONIVERSITY
}

THE COMSTOCK PUBLISHING CO.

ITHACA, NEW YORK

1917 
Open access edition funded by the National Endowment for the Humanities/Andrew W. Mellon Foundation Humanities Open Book Program.

Copyright (C) 1917 by Cornell University

First paperback printing 2019

The text of this book is licensed under a Creative Commons Attribution-NonCommercial-NoDerivatives 4.0 International License: https://creativecommons.org/licenses/by-nc-nd/4.0/. To use this book, or parts of this book, in any way not covered by the license, please contact Cornell University Press, Sage House, 512 East State Street, Ithaca, New York 14850. Visit our website at cornellpress.cornell.edu.

Printed in the United States of America

ISBN 978-1-5017-4056-5 (pbk.: alk. paper)

ISBN 978-1-5017-4058-9 (pdf)

ISBN 978-1-5017-4057-2 (epub/mobi)

Librarians: A CIP catalog record for this book is available from the Library of Congress 


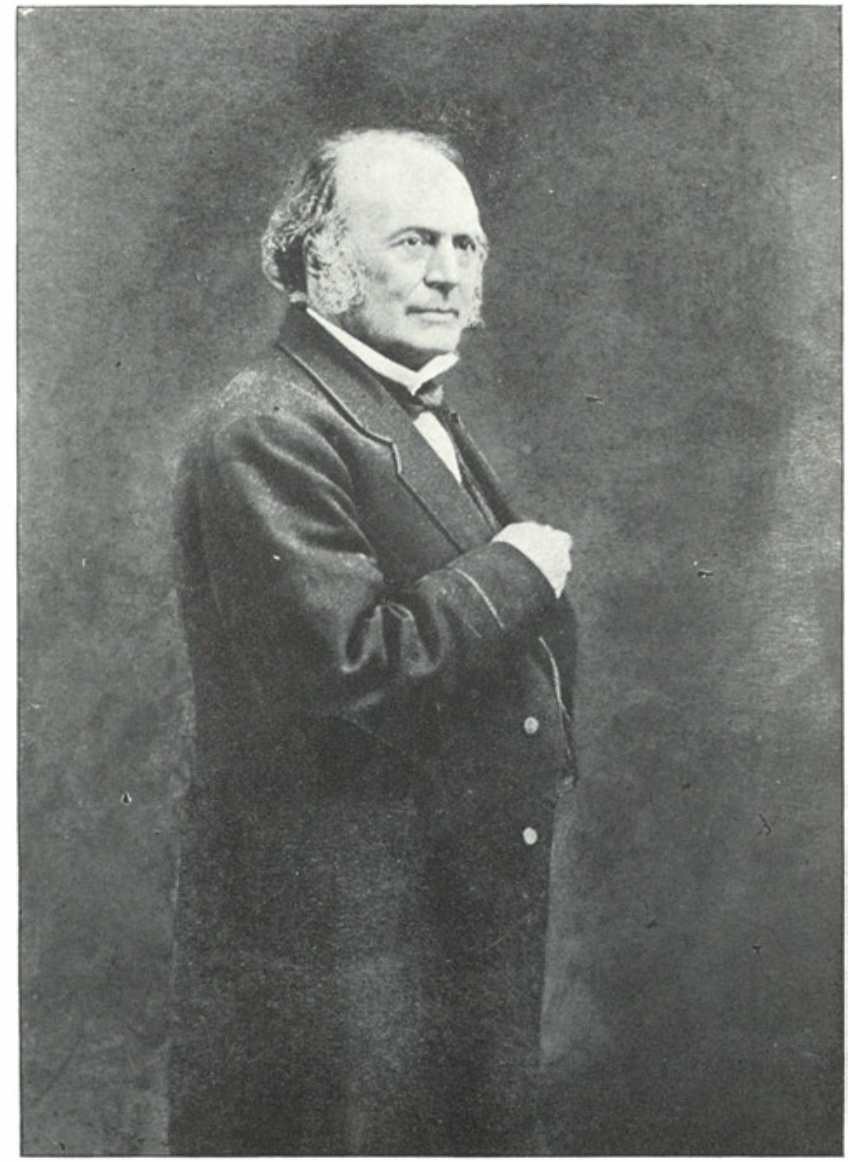

LOUIS AGASSIZ 
The beauty of his better self lives on

In minds he touched with fire, in many an eye

He trained to Truth's exact severity;

He was a Teacher: why be grieved for him

Whose living word still stimulates the air?

In endless file shall loving scholars come

The glow of his transmitted touch to share.

Lowell, Agassiz. 